\title{
Unknown Site of New Tumor Event
}

National Cancer Institute

\section{Source}

National Cancer Institute. Unknown Site of New Tumor Event. NCI Thesaurus. Code C160156.

The site of the new tumor event is unknown. 